\title{
EFFECTS OF INSTITUTIONAL ARRANGEMENTS AND POLICIES ON COMMUNITY PARTICIPATION IN WILDLIFE TOURISM IN AFRICA
}

\author{
Refiloe J. LEKGAU* \\ School of Tourism \& Hospitality, College of Business and Economics, University \\ of Johannesburg, Johannesburg (South Africa), e-mail: rlekgau@uj.ac.za \\ Tembi M. TICHAAWA \\ School of Tourism \& Hospitality, College of Business and Economics, University \\ of Johannesburg, Johannesburg (South Africa), e-mail: tembit@uj.ac.za
}

\begin{abstract}
Citation Lekgau, R.J. \& Tichaawa, T.M., (2019). EFFECTS OF INSTITUTIONAL ARRANGEMENTS AND POLICIES ON COMMUNITY PARTICIPATION IN WILDLIFE TOURISM IN AFRICA. GeoJournal of Tourism and Geosites, 27(4), 1280-1295. https://doi.org/10.30892/gtg.27414-433
\end{abstract}

\begin{abstract}
This study examines the effect of policies and institutional structures on the ability of communities to participate in wildlife tourism in the Kgalagadi Transfrontier Park. The research utilized a qualitative approach with two case study sites being Askam (South Africa) and Tsabong (Botswana). The study incorporated 17 semistructured interviews with tourism stakeholders and 2 focus group discussions with members of the 2 communities, all of whom were purposely selected. It was found that although governing policies from the two countries were generally supportive, the specific park policies were seen to limit the contribution of wildlife tourism to communities' livelihood. Additionally, the institutional arrangements present in the Kgalagadi Transfrontier Park formed some barriers to community participation. Overall, the research provides insight on host community participation in wildlife tourism in the Kgalagadi Transfrontier Park using a cross-border perspective.
\end{abstract}

Keywords: Kgalagadi Transfrontier Park, wildlife tourism, community participation, collaborative management

\section{INTRODUCTION}

Nature-based tourism with the focus on wildlife is an important research theme that increasingly has captured the attention of researchers owing to its growth and the focus on conservation (Ilies et al., 2017; Andronache et al., 2019; Black \& Cobbinah, 2017; Harilal \& Tichaawa, 2018). Carvanche-Franco et al. (2019) found nature-based travel to be growing at an annual rate of $5 \%$ worldwide. Tourism in Sub-Saharan Africa (SSA) is largely dominated by nature-based experiences, as evident by the UNWTO (2015) report which highlighted that $80 \%$ of international travel to the SSA is wildlife-related. This

\footnotetext{
* Corresponding author
} 
clearly denotes growing interest towards wildlife destinations in the sub-continent. Several governments in SSA have begun leveraging wildlife tourism for the attainment of socio-economic benefits and environmental protection (Christie et al., 2013; Thondhlana et al., 2015; Mbaiwa, 2017; UNCTAD, 2017; Chakrabarty et al., 2019). This emerges as the result of protected areas being located within the rural regions of countries, often characterized with low development, high levels of poverty and the lack of effective initiatives to combat these socio-economic conditions (Bhatasara et al., 2013; Belicia \& Islam, 2018; Black \& Cobbinah, 2018). Consequently, wildlife tourism, based on the principles of sustainable development, conservation and community inclusion, has been positioned as a powerful tool for job creation, poverty alleviation, sustainable livelihoods and local economic development for communities residing adjacent protected areas (Bhatasara et al., 2013; Larkin, 2014; Cobbinah et al., 2015; Mbaiwa, 2017; Snyman, 2017; UNCTAD, 2017; Black \& Cobbinah, 2018; Kimbu \& Tichaawa, 2018; Markwell, 2018; Panta \& Thapa, 2018; Zanamwe et al., 2018). Protected areas are recognized as being crucial to the sustainable growth of countries within this region, owing to their competitive advantage in wildlife features and the ability to generate substantial revenues. The present study specifically draws attention to Transfrontier parks, being transboundary protected areas that have received much support from academia, public and international organisations for their great capacity for biodiversity conservation and sustainable development in host communities (Chiutsi \& Saarinen, 2017).

Globally, there are approximately 440 Transfrontier parks, with southern Africa holding 10 of these Transfrontier parks in the region (Bhatasara et al., 2013). The emergence of Transfrontier conservation areas in Southern Africa resulted from the global recognition that the safeguarding of natural resources should take precedence over the international governance boundaries (Bhatasara et al., 2013). Often coined 'peace parks' these transboundary protected areas are widely supported as global solutions to conservation and poverty alleviation (Buscher, 2013). Transfrontier parks are characterised by their multilayer of interests, including bordering communities, governments, international donors and NGOs, as well as the tourism industry (Ramutsindela, 2007; Bhatasara et al., 2013). In this regard, Transfrontier Parks are frequently criticised over their political and institutional nature, in which several studies question the capacity of these protected areas to contribute to job creation and poverty alleviation in host communities as their introduction has since severely marginalised surrounding communities (Ramutsindela, 2007; Bhatasara et al., 2013; Schoon, 2013; Chiutsi \& Saarinen, 2017; Zanamwe et al., 2018). Moreover, Chiutsi \& Saarinen (2017) maintain that transfrontier parks cannot contribute to socio-economic development, through wildlife tourism, without adequate community participation to derive the conceptualised benefits. This study examines the effect of policies and institutional structures on the ability of communities to participate in wildlife tourism in the Kgalagadi Transfrontier Park.

\section{LITERATURE REVIEW}

The role of tourism in conservation and the attainment of development goals have been continuously put forward by several studies (see Atanga, 2019; Harilal \& Tichaawa, 2018; Harilal et al., 2019; Makindi, 2016; Markwell, 2018; Synman, 2017; Zafra-Calvo \& Moreno-Penaranda, 2018). Often, tourism is seen as crucial for the upliftment of the SSA community as it involves the sustainable use of natural resources for economic gain (Synman, 2017). In examining wildlife tourism and host communities in Transfrontier parks, several studies have questioned the role of national governing policies of these protected areas in achieving the socio-economic development goals often interlinked with 
the promotion of wildlife tourism. Specifically, Adu-Ampong (2019) questions the effect of government approach and intervention in tourism development and planning towards providing enabling conditions for developing wildlife tourism that is inclusive and collaborative with host communities. Wildlife tourism development in protected areas has been often referred to as being a political activity in SSA (Cobbinah et al., 2015).

Literature has supported this assertion with numerous studies exerting that constraint on community participation in wildlife tourism are, more often than not, due to the centralized approach to tourism planning and development (Bello et al., 2017; Dikobe, 2012; Cobbinah et al., 2015; Harilal et al., 2019; Manatsha, 2014; Mokobo, 2017; Thondlhana \& Cundill, 2017). For instance, research in Ghana by Cobbinah et al. (2015) found the responsibilities of developing wildlife tourism and conservation to be the centralized and fragmented amongst different government departments, leading to the conceptualized local benefits of the sector not realized by the host communities.

As policies define the approach to tourism development, and subsequently community participation, this necessitates the evaluation of national governing policies on wildlife tourism and conservation in Botswana and South Africa, in order to gain a more holistic understanding of the socio-political context that the Kgalagadi Transfrontier Park operates in. South Africa has two sets of policies that govern tourism and conservation of protected areas in the country. The conservation of protected areas is governed by 11 pieces of national legislation and 9 provincial legislation pieces, these include the 1998 White Paper on Environmental Management, the amended 2003 National Environmental Act, the amended 2003 Environmental Conservation Act, White Paper on Conservation and sustainable use of Biological Diversity, the 2003 National Environmental Management: Protected Areas Act, the 2004 National Biodiversity Act, and the 2006 National Biodiversity Strategy and Action Plan (Steyn \& Spencer, 2011).

The two prominent policies are the Protected Areas Act and the Biodiversity Act which guide the establishment of South African National Parks (SANParks) Management Plans for individual protected areas, and state that the management of protected areas should be in consultation with host communities (Paterson, 2009; SANParks, 2016). Accordingly, SANParks has devised a stakeholder consultation process that park management following in managing natural resources in a manner that also preserves the cultural values (Paterson, 2009). With regards to tourism, the political transformation of South Africa led to the establishment of policies that aim to grow and develop a sustainable and inclusive tourism sector. These policies include 1996 White Paper on the Development and Promotion of Tourism, the National Tourism Sector Strategy, the 2003 Tourism Act, and the Tourism Black Economic Empowerment (BEE) Charter (Steyn \& Spencer, 2011). These policies were established to create opportunities for the private sector, host communities and the national government to capitalise from this economic sector (Manwa \& Modirapula, 2019; Strydom et al., 2019). Additionally, the amended 1994 Restitution of Land Act played a vital role in helping communities reclaim their land from which they were removed from during the colonial period of South Africa.

This Act is especially relevant to the present study as it enabled the Mier and San community to own land segments inside the Kgalagadi Transfrontier Park, as well as enabled the establishment of a forum from which the communities can participate in the management and development of wildlife tourism and conservation in the Kgalagadi Transfrontier Park. Similarly, Botswana has sets of policies and strategies for tourism and conservation. Tourism development in the country is guided by 2000 Botswana Tourism Master Plan, the 2001 Tourism Development Framework, the 2002 Botswana National Ecotourism Strategy (NES), the 1992 Botswana Tourism Act and the 1994 Botswana 
Tourism Regulation (Basupi et al., 2017). These policies were drawn from the realisation of the growing importance of tourism to the national economy and lack of policy framework to govern and grow the sector (Basupi et al., 2017). In 1997, the Community Based Strategy was established to promote community participation and the building of local institutions at the community level in tourism (USAid, 2016). These policies, in particular the NES, aimed at including the community within tourism development in the country. In terms of conservation in protected areas, the Wildlife Conservation Policy, the National Policy on Resources Conservation and Development, the Wildlife Conservation and National Parks Act and the National Conservation Policy created a framework from within which the protection of the natural environment can be guided by stakeholders such as the community (Jones, 1999; Moswete et al., 2012).

These policies additionally highlight the significance of the protected areas to the livelihoods of the communities, acknowledging that communities should derive benefits such as job creation and sustainable livelihoods. Essentially, many studies accentuate the importance of viewing protected areas alongside their cultural and social ties to the host communities, delineating the change to including communities' views and opinions in the planning and management activities regarding the protected areas (Mellon \& Bramwell, 2016; Sabuhoro et al., 2017; Zanamwe et al., 2018; Atanga, 2019).

This collaborative and decentralised approach to wildlife tourism and conservation in protected areas is considered crucial to successful environmental protection and poverty alleviation (Cobbinah et al., 2015; Kossoman et al., 2016; Roy, 2016; Soe \& Yeo-Chang, 2019). Collaborative management emphasises the importance of every tourism stakeholder, irrespective of their level of power, in achieving sustainable growth and conservation (Kossoman et al., 2016). Moreover, this form of managing protected areas paves way for amalgamation of traditional systems and beliefs and modern scientific principles of conservation (Aswani et al., 2017). On the side of the communities, the success of collaborative management lies in communities' level of social capital, which is most evident in their community based natural resource management (CBNRM) programs such as community-based organisations (CBOs), Community Trusts, and Communal Property Associations (CPA).

\section{STUDY CONTEXT}

Formally established in 1999 by Botswana and South Africa, the Kgalagadi Transfrontier Park is the oldest Transfrontier protected area within the SSA continent (Moswete \& Thapa, 2018). The Park is situated southwest of the southern African region (Thondhlana et al., 2015) (see Figure 1). The existence of the park predates years before its formal declaration as a protected area, as the two countries have been unofficially collaborating on conserving the unique biodiversity of the Kgalagadi for approximately over a decade before the official agreement (Botswana Tourism, 2015).

The Kgalagadi Transfrontier Park was formed from the merger of the South African Kalahari Gemsbok National Park and the Botswana Gemsbok Park and estimated to be 38 oookm$^{2}$ (SANParks, 2015). The initial agreement pointed to SANParks governing the South African side of the park and the Department of Wildlife and National Parks to govern the Botswana side of the Transfrontier Park (Moswete et al., 2012). In allowing the free movement of wildlife, the Kgalagadi Transfrontier Park has no borders or fences within, so as to ensure the migration route of wildlife necessary to their survival (Botswana Tourism, 2015).

According to Moswete et al. (2012), the objectives formed between the two countries upon the establishment of the single collaborative entity entailed: 
- protecting the unique Kgalagadi region biodiversity,

- realizing the economic potential for the communities residing adjacent to the park

- maximizing the potential of tourism within the protected area and surrounds

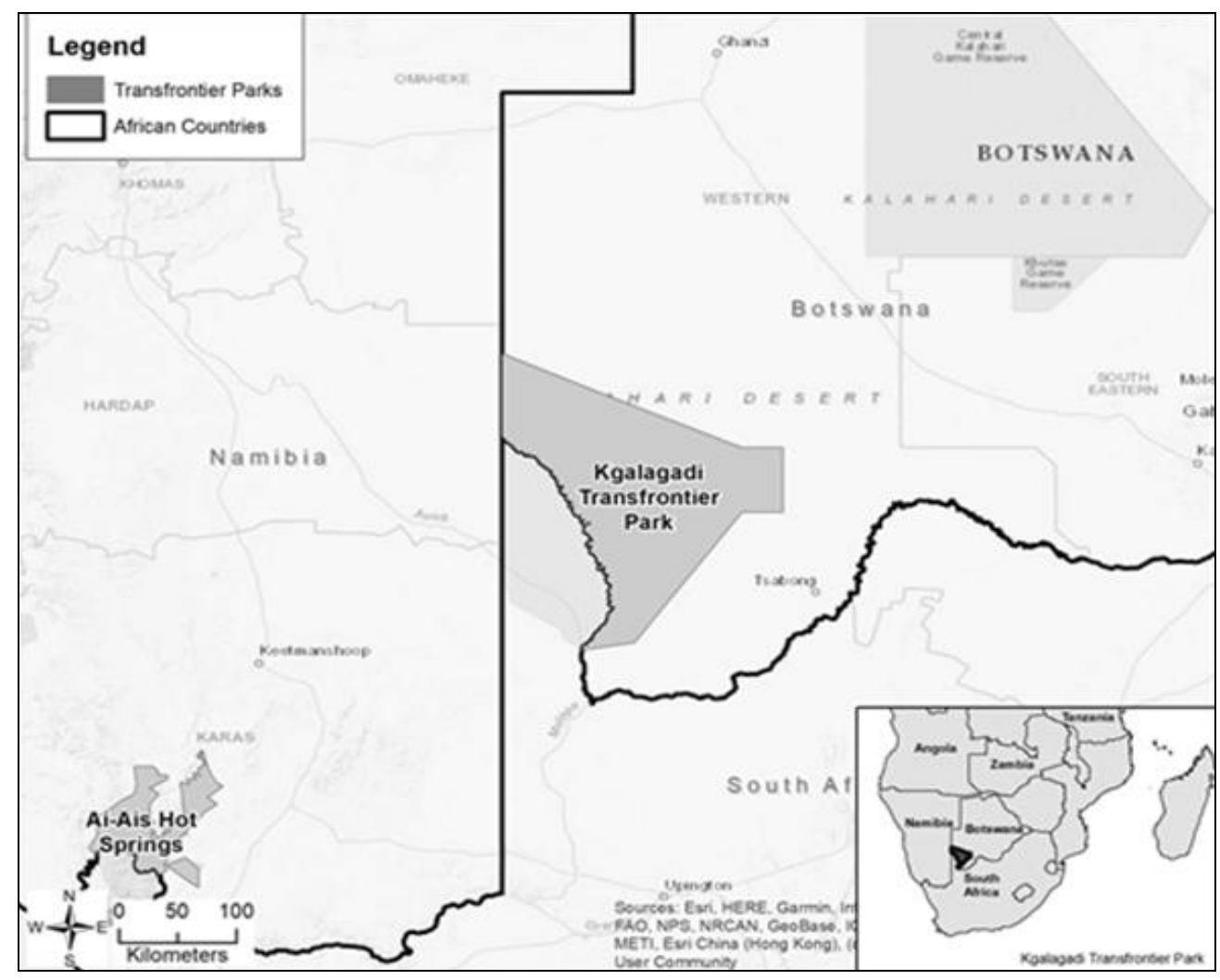

Figure 1. Map of case study sites

As the present study sought to understand the manner in which national governing policies and institutional structures influenced the ability of the community to participate in wildlife tourism and conservation in the Kgalagadi Transfrontier Park, the study focuses on two case study sites, Askham (in South Africa) and Tsabong (in Botswana). The Askham community comprises of the Mier and San communities. These two communities were displaced from the land, and resources, in the Kgalagadi Transfrontier Park years after the establishment of the Kalahari Gemsbok National Park in 1931 (Peace Parks Foundation, 2019). In 1999, the two communities won the land claim and collectively own 50 oooha of land inside the Kgalagadi Transfrontier Park and 80 oooha of land outside the park (Thondhlana et al., 2015). The South African government built a lodge,!Xaus Lodge, inside the park as a means to involve the communities in wildlife tourism (Dikgang \& Muchapondwa, 2016). Tsabong is a transit site for tourists visiting the Kgalagadi Transfrontier Park on the Botswana entry (Manwa et al., 2017). The village is also the administrative capital of the Kgalagadi district and holds the most developed tourism infrastructure, such as telecommunication, electricity, accommodations and airstrips (Saarinen et al., 2012). Further, the Botswana Tourism Organisation (BTO) partnered with the Tsamama Community Trust, which includes the Tsabong community, 
to establish the Camel Park as a link to the Kgalagadi Transfrontier Park and enhance wildlife tourism in the community (Manwa et al., 2017). The two case study sites were selected as both communities are interlinked with the Kgalagadi Transfrontier Park and wildfire tourism from the park is a vital economic sector in the two local economies.

\section{MATERIALS AND METHODS}

The present study utilized a qualitative research approach, as the nature of the study intends on exploring the manner in which communities are affected by tourism and conservation policies from the Kgalagadi Transfrontier Park. The present study focused on the lived experiences and understanding of the communities' reality, requiring a naturalistic and interpretative approach (Babbie, 2013). The study population consisted of two groups, tourism stakeholders and community members. The purposive sampling design was selected, allowing the inclusion of individuals with relevant knowledge and experience in wildlife tourism in the Kgalagadi Transfrontier Park and the inclusion of host communities involved within wildlife tourism and informed on community involvement within the Park. Two data collection tools were utilized in accordance with the study population groups. Semi-structured interviews were held with tourism stakeholders. Specifically, the tourism stakeholders included the formal and informal business owners or managers, representatives of tourism marketers, conservation agencies and CBOs. Open-ended questions were posed to this study sample so as to allow for explorative discussions and probing. In total, 17 interviews were held with tourism stakeholders, 8 in Askham and 9 in Tsabong. Focus group discussions were held with community representatives. Members of the focus group discussions consisted of community members employed in tourism, community leaders, as well as members of the community who had longer length of residence. These community members were postulated to have an understanding of the complexities between wildlife tourism, the community and the Kgalagadi Transfrontier Park. The study held focus group discussions in the case study sites, comprising of 10 participants each. The questions presented to the focus group and interviews pertained to understanding the nature of governing policies of the Kgalagadi Transfrontier Park and their influence of the communities deriving the livelihood needs from the protected area. The data used in the present study were collected during the month of May 2019. The researchers followed the correct ethical procedures which included providing information regarding the study before the commencement of the interviews and focus groups, asking for permission to record the sessions and assuring the research participants that their personal details will remain anonymous. The interviews and focus group discussions were recorded, transcribed and loaded on to Atlas.ti version 8. The qualitative data analysis software enabled the interpretation of the data through the use of codes and family codes. The family coded generated enabled the data to be analysed and discussed thematically, as can be evident in the following section.

\section{RESULTS DISCUSSIONS Guiding policies}

The political nature often interlinked with Transfrontier Park has placed the protected areas under question, particularly regarding the extent to which communities are able to participate in the collaborative management of the park so as to derive the promised livelihood benefits from wildlife tourism. The Kgalagadi Transfrontier Park, in particular, holds a history of community marginalization and separation from the protected area. However, the development of national policies governing conservation, 
tourism and rural development, in both South Africa and Botswana, point to the significance of community consultation and inclusion in planning and development activities within their localities. The literature review illustrated the national South African policies guiding wildlife tourism in the Kgalagadi Transfrontier Park to be conducive for community participation in the sector. Many respondents in the Askham community were generally positive towards the policies guiding wildlife tourism and conservation in the Kgalagadi Transfrontier Park. Some respondents noted the change brought forth by the inclusive policies, explaining that the policies aided in transforming the previously antagonistic relationship between the community and the management of the Kgalagadi Transfrontier Park. One community leader stated:

So the relationship with the park and the community has changed over the years. Last year the community was recipient to the SANParks award that honoured the community for having the best relationship with SANParks in the whole of South Africa. This was because of the efforts on both sides, that is, the community and also top management at SANParks starting to understand that conservation includes the people and not only wildlife. They then recognize that the park is part of the community's cultural footprint.

Such findings reveal the importance of the community being recognized as a central component in the management of the Kgalagadi Transfrontier Parks. One prominent feature in the conflict between host communities and protected area management stems from the marginalization of these communities in the development and promotion of wildlife tourism in the protected areas, resulting in feelings of resentment (see Cobbinah et al., 2015; Thondhlana \& Cundill, 2017). The community representatives have therefore highlighted the significance of showcasing community inclusion and recognizing their ownership in the Kgalagadi Transfrontier Park. Further, this additionally emerges from their community having known their legal rights inside the park, with one representative of the CBO on the side of South Africa stating:

SANParks also have a legal requirement to include community participation, especially for any developments inside the Kgalagadi Transfrontier Park, that's a legal requirement in South Africa. So if SANParks decide to change the gateway inside the park, that's going to have a huge impact in the community, especially because the community has legal rights within the park. They have to carry out a full consultation process, not only at committee level but at the community level, it is part of the management plan that they develop for 5 years.

The above assertion collaborates with the 2016 - 2026 Management Plan of the Kgalagadi Transfrontier Park as complied and adhered to by SANParks. This consultation process clearly stipulated in the Management Plan is also a requirement specified in the Protected Areas Act. The above quotations thereby indicate the national governing tourism and conservation policies are not only supportive of community ownership and participation in the management activities of the Kgalagadi Transfrontier Park, but mandatory. The inclusion of the two communities is particularly important as it enables the realization of the Park objectives that intends to contribute to economic development of the host communities owing to that the community cannot derive consumptive uses from the Kgalagadi Transfrontier Park (as it is a protected area) leading to wildlife tourism being the primary means that community can gain a sustainable livelihood from the park. The increased importance of collaborative management within protected areas 
in southern Africa emerges from the realization that the traditional approach to conservation, characterized by displacement, community loss of access to natural resources and centralized planning, not only failed to protect biodiversity but additionally led to the further impoverishment of indigenous communities (Mbaiwa \& Stronza, 2010; Parker et al., 2015). Collaborative management of the protected areas in SSA is therefore heavily advocated for, in ensuring the sustainability of wildlife tourism and conservation but additionally, that benefits of the sector are equitably distributed amongst stakeholders, particularly the host community. In achieving this collaborative management in the Kgalagadi Transfrontier Park, one of the requirements in winning the land claim, was the establishment of the community forum from within which the community can be involved in the collaborative governance of the park. One respondent, a representative of the local Mier Municipality stated:

There is a forum that has been established. And in the forum, there are some of the Khomani San people, some of the Mier area people and also people from the park are in that committee. So they use that vehicle to communicate with the different communities. And sometimes, they use other means, in which they come to the offices, like this office here. The community office. They come to the Khomani San office the other guys are and they will hand out information there. But vehicle which they use to communicate with the community is the steering committee.

Evidently, the forum has developed to be a means of ensuring that all communities adjacent to the Kgalagadi Transfrontier Park are well informed on park matters, as well as providing the opportunities for the community to express their views on matters regarding tourism development and conservation. The above quotation further sheds light on the importance of information dissemination to the host communities. The forum, as well as the CPA and Mier Municipality, enable information sharing between the communities and the Kgalagadi Transfrontier Park management. Several studies have noted that one aspect of community marginalization in protected area management is through lack of information sharing (see Moswete et al., 2012; Thondhlana \& Cundill, 2017; Harilal \& Tichaawa, 2018). One respondent, a member of the Khomani San CBO, clarified:

I think what is different with our community is the way information is given to the community, so we understand our role in wildlife tourism. I won't say it is perfect, especially because of the way information is sometimes given to communities, it makes it difficult for them to really understand. But what I explained to these organization is, how absorbable this information that they are passing on to the community? Because you can have the correct information, but if people on that level don't understand or grasp what that information is about, they will still say that they still don't understand.

The above statement delineates the importance of not only information sharing but rather the importance of taking account that communities are not widely knowledgeable on wildlife tourism and conservation. Rather, in ensuring that decisions taken reflect the actual views on community, more emphasis should be on how information is disseminated to communities. In this regard, the CPA plays a crucial role in ensuring community involvement in the park decisions by bridging the gap between the community and the Joint Management Board and the Park management. On the side of Botswana, the responses on policies were not as acknowledged, on the count of that wildlife tourism is a newly emerging economic industry in the community. A few respondents recognized the increasing focus on 
developing wildlife tourism in the community, with the Camel Park being frequently mentioned in interviews and focus groups. One respondent, the CBO representative, outlined that "We are still at an early stage but the mandate of the park is to help the community". The Camel Park was established to encourage community-based tourism in Tsabong, and part of the regional development plan to harness the tourism pull from the Kgalagadi Transfrontier Park (Government of Botswana, 2003; Moswete et al., 2012).

\section{Specific Kgalagadi Transfrontier Park policies}

Interestingly, the study found that national governing policies on tourism and conservation were well received within the focus group discussions. Rather, the specific management policies on the Kgalagadi Transfrontier Park were found to be a source of contention in the study. In Askham, many of the respondents were of the view that Kgalagadi Transfrontier Park management placed a higher value on conservation, as compared to wildlife tourism. Some respondent specifically mentioned the difficulty faced when inside the park. One respondent, a member of the community, stated:

The park rules definitely impact wildlife tourism and the community. For example, we have the right to hunt traditionally in the park, we have the right to live traditionally in the park, and we have the right to harvest medicinal plants and other stuff within the park, in our land there. But when we try to live traditionally within the Kgalagadi Transfrontier Park, the park managers come forward with certain rules, with regards to the predators within the Kgalagadi Transfrontier Park, and they tell us not kill certain kinds of poisonous insects and reptiles within the Kgalagadi Transfrontier Park. Those rules and laws are preventing us from living the way we want to live within the Kgalagadi Transfrontier Park and prevent us from taking tourists within the Kgalagadi Transfrontier Park.

The above statement signifies the strain on the park management policies not only on the rights of the communities, rather on their ability to partake in some wildlife tourism activities. The statement may additionally question the extent to which indigenous knowledge is included in the conservation activities of the Kgalagadi Transfrontier Park, as the respondents showed frustration in the warnings against specific hunting activities, stating '...any traditional group knows how to handle certain poisonous reptiles and so on. They know how to find their way around predators.' The inclusion of indigenous knowledge in conservation policies has been widely debated in literature (see Mbaiwa \& Stronza, 2010; Pienaar et al., 2013; Strickland-Munro \& Moore, 2013; Parker et al., 2015; Thondhlana \& Cundill, 2017; Mbaiwa, 2018; Stone \& Nyaupane, 2018). The aforementioned studies argue for the inclusion of the indigenous community's knowledge in modern conservation principles. The argument stems from the dissention that current conservation practices are largely guided by Western principles, calling forth the need for more native knowledge. On the side of Tsabong, interviews with representatives from tourism marketing organisations highlighted some frustration on the specific policies that point to the tourism use of the park.

There are rules that are going to be a hinder for tourism developments. For example, in South Africa you can do the game drive with any type of a vehicle, whether you can take a corolla, a small car and do the drive. But with us you are not allowed small cars. With the Botswana side of the park, you need a specific type of car to do the game drives. Some of the governing rules that we have would hinder some of the desires of the companies that would actually want to do business this side. In the Botswana area. 
The policies within the Kgalagadi Transfrontier Park are noted to affect the growth of community-led wildlife tourism on both sides of the transboundary protected area. However, as the Kgalagadi Transfrontier Park is a protected area, the primary mandate of the park is to conserve biodiversity, which means placing certain restrictions that conflict with some objective of tourism stakeholders, for example, one tourism business owner noted:

They only allow a certain amount of day visitors, per day. So it stops you from expanding, I'm not going to build another 10 chalets

The Kgalagadi Transfrontier Park is a low impact park, resulting in the restrictions on daily visitors. This necessitates deliberate attention on harmonising the management of the Kgalagadi Transfrontier Park and the wildlife tourism development of the host communities, on both sides of the protected area. Both stakeholders in wildlife tourism and conservation need to be aware of the ecological importance of the park, but additionally recognise that the park is a crucial livelihood source for a large portion of communities residing in the Kgalagadi region of both countries.

\section{Effects of institutional structures}

Transfrontier parks, as political entities, involve a number of stakeholders and management bodies in harmonizing the conservation and development of the park in accordance of national policies as well as to satisfy the socio-economic development objectives of the parks. On the side of Askham, the community was generally positive towards the institutional arrangements existing within the Kgalagadi Transfrontier Park. One respondent, a representative of the Mier community, noted:

Every conservation activity that they [Kgalagadi Transfrontier Park] need to make, they need to discuss that on the Joint Management Board [JMB] level. The JMB then brings this information down to the community and the community needs to absorb this and make decisions on it. So the representatives on the JMB are not necessarily decision makers, they come to another body which is the CPA, and the CPA representatives are responsible to get the information out to the community, because they are dealing directly with the community, they are also not supposed to make any decisions. They need to take the decision from the community, especially park related, and the representatives of the JMB needs to make sure that the decision of the community are going to be implemented.

The existence entities such as the JMB and CPA therefore ensure that the views of the community are included in the management and governance activities of the Kgalagadi Transfrontier Park. These entities may additionally facilitate the collaborative management of the park by easing the communication channels between the park managers and the host communities. This strongly results in positive working relationships between park managers and the community, enabling the achievement of each stakeholder's goals, as well as complying to the law. The study therefore finds a much more positive relationship between a host community and protected area management, as many of similar relationships are often characterized by hostility, conflict and resentment, emerging from the difficulty in involving the host communities. An additional feature evident in the Kgalagadi Transfrontier Park is the appointment of a liaison officer, an individual communicating with the various wildlife tourism businesses and organisations such as the Red Dune Route, a collection of tourism businesses offering wilderness experiences in the Kgalagadi region. Evidently, the structures present in the Kgalagadi enable collaborative partnerships with the host communities. Much contention 
seen in the focus group discussions arose with the management structure of SANParks, where majority of participants expressed feelings of frustration over the long management structure of SANParks that does not take account of the local context in planning and decision making. One respondent, a representative of the San CPA, noted:

SANParks is working from a high level of decision making and the decisions taken are implemented on a smaller scale. You have the head office of SANParks in Pretoria, then you have your Arid region manager who is responsible for the different parks falling under Arid region. Then you have your local park manager. So the local park manager relies on the decisions that come from the Arid manager, and the Arid manager implements decisions from the overall manager of SANParks. So by the time the decision is scaled down to the local context, the host community basically don't have any say on the decision that has made at the higher level.

Discussions on sustainable tourism urge more considerations of the local context of the host communities. Particularly in the case of protected areas, the exclusion of this local context may seemingly marginalize communities, bringing forth emotive experiences from past displacement and separation when the protected area was first established (Thondlhana \& Cundill, 2017). Long management structures are often criticized for their inability to be complementary and reflective of the host communities, holding the risk of developing wildlife tourism and conservation that is not complementary to the host community. Such findings are particularly significant as they may suggest that the more important decisions are taken at the higher institutional level, and discussions are not concluded with the aid of the communities, thereby explaining community perception of conservation having more precedence over tourism development in the Kgalagadi Transfrontier Park. Further consideration should be placed on that much of the livelihood activities of the communities in the Askham is reliant on the Kgalagadi Transfrontier Park, the protected area is positioned to bring forth economic development in the adjacent communities owing to the lack of mainstream economic activities communities can partake in. This may make it more important to ensure that wildlife tourism and conservation decisions taken in SANParks are more complementary to the host communities and setting. In broadening the discussion, one respondent, a representative from the Mier Local Municipality, stated:

It is a lot of structures that you have to go through in SANParks, because sometimes they [SANParks] do not seek prior consent for something 'small'. Now they can see it as something small, the community sees it as huge because maybe it had to do with some structure that is formed close to the heritage site, which they do not feel comfortable with. SANParks now may not have understood exactly why the community felt that way. And this is because they were thinking from a conservation management principle and not from an overall management system.

The above statement thereby indicates the challenges faced by the host communities in the management of the Kgalagadi Transfrontier Park, calling forth a more comprehensive perspective to be taken in all park related decisions. This additionally supports the aforementioned discussion on the inclusion of indigenous knowledge in park related decisions, as SANParks take may seemingly minor impact decision only for those decisions to have a significant impact on the community. This highlights the transformation of protected areas, from being a mode in conservation to carrying both 
ecological and social responsibility (Kossoman et al., 2016; Makindi, 2016). Protected areas must be viewed alongside the host communities, and therefore their cultural ties to the protected area should be respected in the planning and development of wildlife tourism and conservation. Another obstacle faced by the community is the matter of additional institutional structures within the Kgalagadi Transfrontier Park as a result of the inscription of the World Heritage Site. This brings forth more considerations in the planning and development decisions of the protected area in itself. Some respondents felt that this may lead to more planning decisions, that although are conceptualized to be inclusive of the San community, may need more and deliberate efforts to ensure more than adequate information sharing. For example, one community leader stated:

\begin{abstract}
But what also comes into consideration, is this new heritage site. The entire Kgalagadi park is a World Heritage Site, so that comes with a new technical committee that is a different form of decision making and information sharing that has to be included in the institutional arrangements in the area. So in our community perspective, there is a lot of developments and that's based on decision making processes that sometimes does not have enough time to properly get to the stage where the community can properly, completely understand what is going on. So it is about sharing the basics constantly.
\end{abstract}

The existence of numerous structures within wildlife tourism and the host communities may prove to be challenging for collaborative management. For the Khomani San community, the CPA enables them to be involved in park decisions as well as decisions regarding the heritage site. This is extremely important as Transfrontier conservations are already criticized for their likelihood of marginalizing communities owing to number of stakeholders involved in both countries. The addition of the heritage site adds a new set of management principles in accordance to UNESCO, calling on more collaboration. The CPA shows high levels of social capital in embedding within the various institutional structures to ensure the Khomani San community is included in all that occurs in the Kgalagadi region of South Africa. This was evident in one respondent mentioning that "The Khomani San have very big influence in what is happening in the surroundings" highlighting their prominence in the region.

On the side of Tsabong, the study found many of the community respondents being of the view that wildlife tourism and conservation were isolated from the community, in that the wildlife tourism structures had not fully integrated with the local traditional structures. Some respondents in the focus group discussions pointed out that these wildlife tourism structures were stand-alone entities, and not collaborating with the community development entities such as the Village Development Committee (VDC). For instance, one respondent, a VDC representative presented:

We, as the VDC, are responsible for the development projects in Tsabong. Now since [the department of] tourism has entered Tsabong, we know nothing about it. You see with agriculture and other sectors we know a lot about it because these are the community projects that we usually assess and help. They [Department of Tourism] are the ones who are supposed to come to the VDC to tell us how they help the community and we advise them how they can go about this.

This finding was supported with the focus group responses where the majority of the community leaders strongly expressed their lack of knowledge on wildlife tourism in the community, besides the sector's existence. This may be to the disadvantage of both 
wildlife tourism and conservation structures, as well as the community as Pansiri (2013), viewed networks as essential component within wildlife tourism and host communities, in that networks enabled the various tourism stakeholders to work collaboratively to achieve similar collective and individual objectives. The lack of collaboration on wildlife tourism and host communities may delay the attainment of the conceptualised benefits of the economic sector. Moreover, one respondent, a community leader, supported:

Really we don't know much about them [wildlife tourism institutions]. Because from our side, they haven't come and taught us anything about wildlife tourism, so we can understand it. So we as the community leaders don't know them.

These findings corroborate with the findings of Moswete et al. (2012) where communities expressed disconnect from wildlife tourism and the Kgalagadi Transfrontier Park. This can be rather challenging to wildlife tourism, as the sector is aimed to encourage the protection and change to positive attitudes towards the natural environment. The lack of community engagement may lead to not only the failure to include the community in conservation of the environment but that the sector may not achieve what it has sought out to do, being to induce socio-economic development in the village. Community organisations such as the VDC and the Kgotla may be very influential in galvanising community members to participate in wildlife tourism. Moreover, should such occurrences of separation continue, this may lead to negative perceptions from the community towards wildlife tourism.

However, one reason for the lack of community collaboration with wildlife tourism may be a result of that communities can only take part in wildlife tourism, by the utilisation of natural resources, through CBOs. CBOs are a legal requirement to community participation in wildlife tourism, thereby pointing to that the wildlife tourism institutions may be closely collaborating with the Tsamama CBOs, and rather only exchanging information with the local traditional structure.

Interestingly, although the community strongly asserted their disengagement from wildlife tourism management and development in Tsabong, the interviews yielded a contradictory response. The interview respondents affirm their inclusion of communities in their planning and development decisions regarding wildlife tourism and conservation in Tsabong. One respondent, a conservation agency representative, named the kgotla, the traditional community structure, as one way of exchanging information with the community regarding new developments.

The kgotla is the main medium we use to communicate with the community because that way you cover all the structures of communication, so kgotla is the main one. But also the institutions such as the trusts system and CBO systems have so grown that much that they are taking the lead in natural resources management. But they [CBOs] are still using the same medium as the kgotla.

Additionally, from the side of wildlife tourism institutions, one respondent clearly stated their incorporation of community views with regards to decisions involving their natural resources and new developments, for example:

Yes, communities are consulted for their views before decisions are made, and impacts are discussed. If I can give you an example, a conservation area by Khawa, is going to be privatized. Consultation was had with the community, by my view, the community members were happy as their children and them were going to be hired. 
Consequently, these respondents wholly differ from the responses received from the community focus group discussions. This may be a consequence of the fact that these stakeholder groups are at two ends of the Kgalagadi Transfrontier Park spectrum, where one group is responsible for the management and governance of wildlife tourism and conservation activities and the other is on the receiving end in that wildlife tourism is an occurrence in their locality. These findings built on those of Moswete et al. (2012) and Schoon (2013) in that wildlife tourism may not have made great strides in their collaboration with host communities, however, they have made some progress in involving the community in their own development.

\section{CONCLUSION}

The present study examined the political and institutional nature of the Kgalagadi Transfrontier Park with regards to the facilitation of community participation in wildlife tourism. Based on the study findings, it can be concluded that much strides have been taken to include the Askham and Tsabong communities in wildlife tourism and conservation from the Kgalagadi Transfrontier Park. Policies of both countries are supportive of communities taking centre role in the management of protected areas, so as to derive socio-economic benefits. The study found institutional structures posing a strong barrier of meaningful community participation in wildlife tourism on both case study sites. The study augments the discussion on the disparities between the good conceptualisation of policies and their actual implementation. Although the study cannot be generalised to other Transfrontier parks in southern Africa, it may be informative regarding the effects of institutional structures on enabling the development of tourism to encompass with the local context of the host communities.

The study additional implies the need to address the rift between tourism and conservation goals between protected areas, educating communities on the importance of conservation as the chief objective while creating positive conditions for the community to derive wildlife tourism related uses from protected areas.

\section{Acknowledgements}

This research forms part of a dissertation at the University of Johannesburg. The authors would like to thank the University of Johannesburg for funding this study.

\section{REFERENCES}

Adu-Ampong, E.A. (2019). Historical Trajectories of Tourism Development Policies and Planning in Ghana, 1957-2017. Tourism Planning \& Development, 16:2):124-141.

Andronache, I., Marin, M., Fischer, R., Ahammer, H., Radulovic, M., Ciobotaru, A. M., et al. (2019). Dynamics of forest fragmentation and connectivity Using particle and fractal Analysis. Scientific reports, 9(1), 1-9.

Aswani, S., Albert, S. \& Love, M. (2017). One Size Does Not Fit All: Critical Insights For Effective CommunityBased Resource Management in Melanesia. Marine Policy, 81:381-391.

Atanga, R.A. (2019). Stakeholder Views on Sustainable Community-based Ecotourism: A Case of the Paga Crocodile Ponds in Ghana. GeoJournal of Tourism and Geosites, 25(2), 321-333

Babbie, E. (2013). The practice of social research. $13^{\text {th }}$ edition. Belmont: Wadsworth Cengage Learning.

Basupi, B., Pansiri, J. \& Lenao, M. (2017). Botswana Tourism Policy Landscape-Successes and Challenges. Botswana Journal of Business, 10(1), 83-96

Belicia, T. X. \& Islam, M. S. (2018). Towards a Decommodified Wildlife Tourism: Why Market Environmentalism is Not Enough for Conservation. Societies, 8(59), 1-15.

Bello, F. G., Loelock, B. \& Carr, N. (2017). Constraints of Community Participation in Protected Area-based Tourism Planning: The Case of Malawi. Journal of Ecotourism, 16(2), 131-151.

Bhatasara, S., Nyamwanza, A. M., \& Kujinga, K. (2013). Transfrontier Parks and Development in Southern Africa: The Case of the Great Limpopo Transfrontier Park. Development Southern Africa, 3o(4-5), 629-639.

Black, R. \& Cobbinah, P. B. (2018). Local Attitudes Towards Tourism and Conservation in Rural Botswana and Rwanda. Journal of Ecotourism, 17(1), 79-105. 
Buscher, B. (2013). Transforming the Frontier: Peace Parks and the Politics of Neoliberal Conservation in Southern Africa. Durham: Duke University Press.

Carvanche-Franco, M., Segerra-Ona, M. \& Carrascosa-Lopez, C. (2019). Motivations Analysis in Ecotourism through an Empirical Application: Segmentation, Characteristics and Motivations of the Consumer. GeoJournal of Tourism and Geosites, 24(1), 60-73.

Chakrabarty, P., Pan, S. \& Mandal, R. (2019). Promoting Wildlife Tourism on Geotourism Landscape: A Study in Manas and Kaziranga National Parks of Assam, India. GeoJournal of Tourism and Geosites, 24(1), 189-200.

Chiutsi, S. \& Saarinen, J. (2017) Local Participation in Transfrontier Tourism: Case of Sengwe Community in Great Limpopo Transfrontier Conservation Area, Zimbabwe. Development Southern Africa, 34(3), 260-275.

Christie, I., Fernandes, E., Messerli, H., \& Twining-Ward, L. (2013). Tourism in Africa: Harnessing Tourism for Growth and improved livelihoods. Washington DC: World Bank.

Cobbinah, P.B., Black, R. \& Thwaites, R. (2015). Ecotourism Implementation in the Kakum Conservation Area, Ghana: Administration Framework and Local Community Experiences. Journal of Ecotourism, 14(2-3), 223-242.

Dikgang, J. \& Muchapondwa, E. (2016). The effects of land restitution on poverty reduction amongst the Khomani San 'Bushmen' in South Africa. South African Journal of Economics, 84(1),63-80.

Dikobe, L. (ed.). (2012). Consolidating Community Based Natural Resource Management through Effective Stakeholder Engagement, Proceedings of the $6^{\text {th }}$ CBNRM Bi-Annual Conference: Botswana CBNRM National Forum, Gaborone.

Government of Botswana (GoB). (2003). Kgalagadi District Development Plan 6: 2003 - 2009. Gaborone: Government Printers.

Harilal, V., \& Tichaawa, T. M. (2018). Ecotourism and Alternative Livelihood Strategies in Cameroon's Protected Areas. EuroEconomica, 1(37), 133-148.

Harilal, V., Tichaawa, T. M. \& Saarinen, J. (2019). Development without Policy: Tourism Planninf and Research Needs In Cameroon, Central Africa. Tourism Planning \& Development, 16(16), 696-705.

Ilieș, D.C. Baias, S., Buhaș, R., Ilieș, A., Herman, G.V., Gaceu, O., Dumbravă, M. \& Măduţa, F. (2017). Environmental Education in Protected Areas. Case Study from Bihor County, Romania, Geojournal of Tourism and Geosites, 19(1):126-132.

Jones, B.T.B. (1999). Community-Based Nature Resource Management in Botswana and Namibia: An Inventory and Preliminary Analysis of Progress. Evaluating Eden Series, Discussion Paper No.6, 1-95. IIED.

Kimbu, A., \& Tichaawa, T. M. (2018). Sustainable Development Goals and Socio-economic Development Through tourism in Central Africa: Myth or Reality? GeoJournal of Tourism and Geosites, 23(3), 780-796.

Kossomann, C.M., Behgel, J. \& Bailey, M. (2016). Action and Inertia in Collaborative Governance. Marine Policy, 72, 21-30.

Larkin, L. R. (2014). Human-Wildlife Conflict in Maasai Mara National Reserve: Demonstrating the Need for an International Framework on Wildlife-based Tourism. Journal of International Wildlife Law \& Policy, 17(1), 1-31.

Makindi, S. M. (2016). Local Communities, Biodiversity Conservation and Ecotourism: A Case Study of the Kimana Community Wildlife Sanctuary, Kenya. African Journal of Hospitality, Tourism and Leisure, 5(3), 1-15.

Manatsha, B. T. (2014). The Politics of Tachila Nature Reserve in the North East District, Botswana: A Historical Perspective. South African Historical Journal, 66(3), 521-545.

Manwa, H., Saarinen, J., Althopeng, J.R. \& Hambira, W.L. (2017). Sustainability Management and Tourism Impacts on Communities: Residents' Attitudes in Maun and Tsabong, Botswana. African Journal of Hospitality, Tourism and Leisure, 6(3), 1-5.

Manwa, H. \& Modirapula, T. (2019). The Role of Botsalano Game Reserve in Sustainable Livelihoods and Poverty Alleviation Through Community-based Tourism Development in South Africa. African Renaissance, 16(1): 315-333.

Markwell, K. (2018). An Assessment of Wildlife Tourism Prospects in Papua New Guinea. Tourism Recreation Research, 43(2), 250-263.

Mbaiwa, J. E. (2017). Poverty or Riches: Who Benefits From Booming Tourism Industry in Botswana? Journal of Contemporary African Studies, 35(1), 93-122.

Mbaiwa, J.E. (2018). Effects of safari hunting ban on rural livelihoods and wildlife conservation in Northern Botswana. South African Geographical Journal, 100(1),41-61.

Mbaiwa, J. E. \& Stronza, A. L. (2010). The Effects of Tourism Development on Rural Livelihoods in the Okavango Delta, Botswana. Journal of Sustainable Tourism, 18(5), 635-656.

Mellon, V. \& Bramwell, B. (2016) Protected Area Policies and Sustainable Tourism: Influences, Relationships and Co-evolution. Journal of Sustainable Tourism, 24(10), 1369-1386.

Moswete, N. \& Thapa, B. (2018). Local Communities, CBOs/Trusts, and People-Park Relationships: A Case Study of the Kgalagadi Transfrontier Park, Botswana. The George Wright Forum, 35 (1), 96 - 108.

Moswete, N., Thapa, B., \& Child, B. (2012). Attitudes and Opinions of Locals and National Public Sector Stakeholders Towards Kgalagadi Transfrontier Park, Botswana. International Journal of Sustainable Development \& World Ecology, 19(1), 67-80.

Mukobo, N. (2017). The Role of Transfrontier Conservation Areas and Their Institutional Framework in Natural Resource-based Conflict Management: A Review. Journal of Sustainable Forestry, 36(6):583-603. 
Effects of Institutional Arrangements and Policy

on Community Participation in Wildlife Tourism in Africa

Pansiri, J. (2013). Collaboration and Partnership in Tourism: The Experience of Botswana. Tourism Planning \& Development, 10(1), 64-84.

Panta, S. K. \& Thapa, B. (2018). Entrepreneurship and Women's Empowerment in Gateway Communities of Bardia National Park, Nepal. Journal of Ecotourism, 17(1), 20-42.

Parker, P., Thapa, B. \& Jacob, A. (2015). Decentralizing Conservation and Diversifying Livelihoods within Kanchenjungo Conservation Area, Nepal. Journal of Environmental Management, 164,96-103.

Paterson, A.R. (2009). Legal framework for protected areas: South Africa. Gland: IUCN.

Pienaar, E.F., Jarvis, L.S. \& Larson, D.M. (2013) Creating Direct Incentives for Wildlife Conservation in Community Based Natural Resource Management Programmes in Botswana. Journal of Development Studies, 49(3):315-333.

Ramutsindela, M. (2007). Globalisation and Nature Conservation Strategy in the 21th Century Southern Africa. Journal of Economic \& Social Geography, 95(1): 61-72.

Roy, A.K.D. (2016). Local community attitudes towards mangrove forest conservation: Lessons from Bangladesh. Marine Policy, 74,186-194.

Saarinen, J., Hambira, W.L., Althopeng, J. \& Manwa, H. (2012). Tourism Industry Reaction to Climate Change in Kgalagadi South District, Botswana. Development Southern Africa, 29(2), 273-285.

Sabuhoro, E., Wright, B. A., Munanura, I., \& Nyakabwa, I. N. (2017). The Potential of Ecotourism Opportunities to Generate Support for Gorilla Conservation Amongst Local Communities Neighboring Volcanoes National Park in Rwanda. Journal of Ecotourism, 1-17.

Schoon, M. (2013). Governance in Transboundary Conservation: How Institutional Structure and Path Dependence Matter. Conservation \& Society, 11(4), 420-428.

Snyman, S. (2017). The Role of Private Sector Ecotourism in Local Socio-economic Development in Southern Africa. Journal of Ecotourism, 16(3), 247-268.

Soe, K. T., \& Yoe-Chang, Y. (2019). Perceptions of Forest-dependent Communities Towards Participation in Forest Conservation: A Case Study in Bago Yoma, South Central Myanmar. Forest Policy and Economics, 100, 129-141.

Steyn, J.N. \& Spencer, J.P. (2011). South African Tourism: An Historic Evaluation of Macro Tourism Policies. African Journal for Physical, Health Education, Recreation and Dance, 17(2), 178-200.

Stone, M. T. \& Nyaupane, G. P. (2018). Protected Areas, Wildlife Based Community Tourism and Community Livelihood Dynamics: Spiralling Up and Down of Community Capitals. Journal of Sustainable Tourism, 26(2), 307-324.

Strickland- Munro, J. \& Moore, S. (2013). Indigenous Involvement and Benefits from Tourism in Protected Areas: A Study of Purnululu National Park and Warmun Community, Australia. Journal of Sustainable Tourism, 21(1), 26-41.

Strydom, A.J., Mangope, D. \& Henama, U.S. (2019). Making Community-Based Tourism Sustainable: Evidence from the Free State Province, South Africa. GeoJournal of Tourism and Geosites, 24(1), 7-18.

Thondhlana, G., \& Cundill, G. (2017). Local People and Conservation Officials' Perceptions on Relationships and Conflicts in South African Protected Areas. International Journal of Biodiversity Science, Ecotourism Services \& Management, 13(1), 204-215.

Thondhlana, G., Shackleton, S., \& Blignaut, J. (2015). Local Institutions, Actors and Natural Resources Governance in Kgalagadi Transfrontier Park and Surrounds, South Africa. Land Use Policy, 47, 121-129.

Zafra-Calvo, N. \& Moreno-Peñaranda, R. (2018). Exploring local people's views on the livelihood impacts of privately versus community managed conservation strategies in the Ruvuma landscape of North Mozambique-South Tanzania. Journal of Environmental Management, 206,853-862.

Zanamwe, C., Gandiwa, E., Mukobo, N., Kupika, O. L. \& Mukamuri, B. B. (2018). Ecotourism and Wildlife Conservation-related Enterprise Development by Local Communities within Southern Africa: Perspectives From the Greater Limpopo Transfrontier Conservation, South-Eastern Lowveld, Zimbabwe. Cogent Environmental Science, 4, 1-13.

*** Botswana Tourism. (2015). Travel Companion: Kgalagadi/Central. Gaborone: BTO.

*** Peace Park Foundation (2019). Kgalagadi. Available at: https://www.peaceparks.org/tfcas/kgalagadi/ [Accessed 18 August 2019].

*** South African National Parks (SANParks). (2016). Kalahari Gemsbok National Park Management Plan 2016-2026. Pretoria: SANParks.

**** South African National Parks (SANParks). (2015). Arid Parks: Boundless across countries. Pretoria: SANParks.

**** United Nations Conference on Trade and Development [UNCTAD]. (2017). Economic Development in Africa Report 2017. Tourism for Transformative and Inclusive Growth. Geneva: UNCTAD.

*** United Nations Word Tourism Organisation (UNWTO). (2015). Towards Measuring the Economic Value of Wildlife Watching Tourism in Africa - Briefing Paper. Madrid: UNWTO.

*** US Agency for International Development (US Aid). Centre for Applied Research. (2016). Review of Community-Based Natural Resource Management in Botswana. Report prepared for Southern African Environmental Programme (SAREP).

Submitted:

27.07.2019
Revised:

11.12.2019
Accepted and published online 13.12.2019 